\title{
Axoplasmic Transport of Noradrenaline in the Sciatic Nerves of Spontaneously Diabetic Mice
}

\author{
A. Giachetti \\ Department of Pharmacology, University of Texas Health Science Center, Dallas, Texas, USA
}

\begin{abstract}
Summary. The intraaxonal transport of noradrenaline and tyrosine hydroxylase was studied in the sciatic nerves of diabetic, obese and appropriate control mice. Noradrenaline and tyrosine hydroxylase accumulated proximal to a constriction applied to the nerves. Noradrenaline concentration in the non-constricted sciatic nerves did not differ significantly in nondiabetic and diabetic mice $(0.67 \pm 0.04$ and $0.58 \pm 0.01 \mathrm{ng} / \mathrm{cm}$ respectively); in obese mice and lean littermates the noradrenaline concentration was $0.47 \pm 0.05 \mathrm{ng} / \mathrm{cm}$ and $0.46 \pm 0.01 \mathrm{ng} / \mathrm{cm}$. After nine hours of constriction the concentration of noradrenaline increased in the axons of nondiabetic $(1.15 \pm 0.06 \mathrm{ng} / \mathrm{cm})$, in obese $(0.90 \pm 0.08 \mathrm{ng} / \mathrm{cm})$ and lean mice $(1.10 \pm 0.07 \mathrm{ng} / \mathrm{cm})$ but remained low $(0.68 \pm 0.07 \mathrm{ng} / \mathrm{cm})$ in diabetic mice. - Administration of insulin $(10 \mathrm{U} / \mathrm{kg} / \mathrm{day})$ to diabetic mutants completely reversed the decrease in NA accumulation. NA accumulated only in the nerve segment proximal $(1 \mathrm{~cm})$ to a constriction and was transported distally at an apparent velocity of $0.75 \mathrm{~mm} / \mathrm{hr}$ in control axons. The difference of NA accumulation between diabetic and nondiabetic control indicate a reduced rate of axoplasmic flow in the noradrenergic axons of diabetic animals.
\end{abstract}

Key words: Diabetic neuropathy, axoplasmic transport, noradrenaline, tyrosine hydroxylase.

The decrease of conduction velocity, frequently observed in motor and sensory nerves of long-term diabetic patients, has been attributed to segmental demyelination of distal nerves [1]. There are, however, disturbances of conduction, observed in human juvenile diabetics [2] and in experimental diabetes of rats $[3,4]$, which are not accompanied by morphological changes of the myelin sheath. Recently the reduction of intraaxonal flow of proteins has been proposed as an explanation for the impairment of nerve function [5]. Axoplasmic flow has scarcely been investigated in diabetes and the available studies concern the cholinergic neurons of streptozotocin diabetic rats [5]. In the present study axoplasmic flow in the noradrenergic axons present in the sciatic nerves of spontaneously diabetic and obese mice have therefore been investigated. The proximo-distal flow was estimated by measuring the accumulation of noradrenaline (NA) and of tyrosine hydroxylase (TH) (EC 1.14.16.2), an enzyme involved in its synthesis, in constricted nerves.

\section{Materials and Methods}

Spontaneously diabetic ( $\mathrm{C} 57 \mathrm{BL} / \mathrm{KsJ} \mathrm{db} / \mathrm{db}$, male), nondiabetic mice (C57 BL/KsJ ?/+, male), obese (C57 BL/6J ob/ob, male) and lean (C57 BL/6J ?/+, male) were obtained from Jackson Laboratories. They were used between 27 and 33 weeks of age. For the axoplasmic flow experiments the right sciatic nerves were constricted, under ether anaesthesia, by applying a silk ligature around the isolated nerves. The left nerves were isolated but not ligated. Pargyline $(75 \mathrm{mg} / \mathrm{kg} \mathrm{IP})$, an inhibitor of monoamine oxidase, was administered to protect noradrenaline from destruction. At times indicated in the text mice were killed; both sciatic nerves were carefully excised and placed on a cold surface. For noradrenaline determinations, segments of nerves $(1 \mathrm{~cm})$ were homogenized in a glass homogenizer in $0.3 \mathrm{ml}$ of $\mathrm{HClO}_{4} 0.1 \mathrm{~mol} / \mathbf{l}$ containing asorbic acid $(50 \mu \mathrm{g} / \mathrm{ml})$. After a brief centrifugation $(13,000 \times \mathrm{g} \times 10 \mathrm{~min})$ the homogenates were kept frozen until analyzed. The content of noradrenaline was determined on duplicate aliquots $(0.1 \mathrm{ml})$ of supernatant by the radioenzymatic procedure based on the $\mathrm{N}$-methylation of noradrenaline by the enzyme phenylethanolamine transferase (EC 2.1.1) [6]. In our hands this procedure detects $0.025 \mathrm{ng}$ of NA; routinely we used standards of $0.050 \mathrm{ng}$ and $0.250 \mathrm{ng}$ of NA. The protein content in nerve segments was determined on the material precipitated by $\mathrm{HClO}_{4}$ during homogenization as follows: the pellet was washed once with 
Table 1. Noradrenaline content in the sciatic nerve of genetically diabetic and obese mice

\begin{tabular}{|c|c|c|c|c|c|c|}
\hline \multirow[b]{3}{*}{ Group } & \multirow[b]{3}{*}{ Genotype } & \multirow{3}{*}{$\begin{array}{l}\text { Body } \\
\text { weight } \\
\text { (g) }\end{array}$} & \multirow{3}{*}{$\begin{array}{l}\text { Blood } \\
\text { glucose } \\
(\mathrm{mg} / 100 \mathrm{ml})\end{array}$} & \multicolumn{3}{|c|}{ Noradrenaline ( $\mathrm{ng} / \mathrm{cm}$ nerves \pm SEM) } \\
\hline & & & & \multirow[b]{2}{*}{ Contralateral } & \multicolumn{2}{|c|}{ Constricted time } \\
\hline & & & & & $4.5 \mathrm{~h}$ & $9 \mathrm{~h}$ \\
\hline Nondiabetic & C57 BL/KsJ ?/+ & $34.0 \pm 1.5$ & $170 \pm 15$ & $0.67 \pm 0.04$ & $0.67 \pm 0.04$ & $1.15 \pm 0.06$ \\
\hline Diabetic & $\mathrm{C} 57 \mathrm{BL} / \mathrm{KsJ} \mathrm{db} / \mathrm{db}$ & $61.0 \pm 1.84$ & $402 \pm 16$ & $0.58 \pm 0.01$ & $0.60 \pm 0.05$ & $0.68^{\mathrm{a}} \pm 0.04$ \\
\hline Lean & C57 BL/6J ?/+ & $31.5 \pm 2.5$ & $173 \pm 5$ & $0.46 \pm 0.01$ & - & $1.10 \pm 0.07$ \\
\hline Obese & C57 BL/6J ob/ob & $61.2 \pm 1.6$ & $303 \pm 6$ & $0.47 \pm 0.05$ & - & $0.90^{\mathrm{b}} \pm 0.08$ \\
\hline
\end{tabular}

Figures are mean \pm s. e. m. of six observations for diabetic and their littermates and five for obese and lean mice. Diabetic mice and their controls were 27-30 weeks old; obese and lean mice were 33 weeks old. Protein content was (mg/cm) 0.23 for nondiabetic and 0.18 for diabetic

${ }^{a}$ Differs from nondiabetic $(\mathrm{P}<0.001)$

b Not statistically different from control (lean)

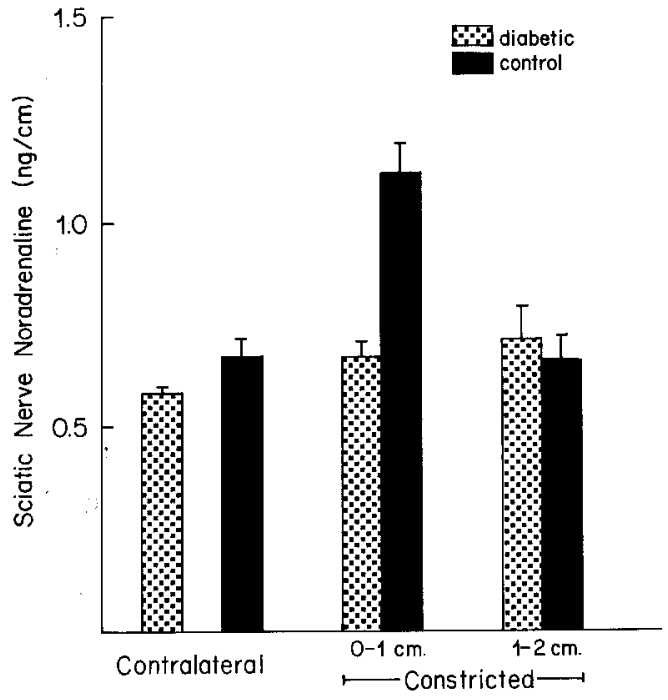

Fig. 1. Distribution of noradrenaline in the sciatic nerves of spontaneously diabetic (dotted) and nondiabetic mice (solid). Right sciatic nerves were constricted, for $9 \mathrm{~h}$; the segment proximal to the ligature $(0-1 \mathrm{~cm})$ in control mice contained significantly more noradrenaline $(\mathbf{P}<0.001)$ than contralateral nerves. Contralateral nerves designates left nerve segments of the same animals. Each bar \pm SEM is the mean of nine observations

$0.5 \mathrm{ml}$ of $\mathrm{H}_{2} \mathrm{O}$ and resuspended in $0.5 \mathrm{ml}$ of $1 \mathrm{~mol} / 1 \mathrm{NaOH}$ by applying a brief sonication $(30 \mathrm{sec}$ ). Proteins were assayed on aliquots of the resuspension [7]; bovine serum albumin served as standard. Tyrosine hydroxylase in sciatic nerves was assayed as follows: Segments of nerves $(1 \mathrm{~cm})$ were homogenized in $0.125 \mathrm{ml}$ of phosphate buffer, $0.5 \mathrm{~mol} / \mathrm{l}, \mathrm{pH} 6.2$, containing $1 \%$ Triton. After a brief centrifugation, the enzyme activity was assayed on aliquots $(0.05 \mathrm{ml}$ in duplicate) of the supernatant according to Waymire et al. [8]. The results were expressed as pmol of 3-4 dihydroxyphenylalanine (DOPA) formed. Blood glucose was determined by a glucose oxidase method (Glucostat, Worthington) in blood obtained from the jugular vein of lightly anaesthetised non-fasted mice.

Statistical analysis was performed by Student's $t$ test using paired or unpaired comparisons. Adenosyl-1-methionine-S(methyl $-{ }^{3} \mathrm{H}$ ) and ${ }^{14} \mathrm{C}$ tyrosine were obtained from Amersham, Arlington Heights, Ill., USA. Pargyline was a gift from Abbott
Labs, Chicago, Ill., USA; all other chemicals were from Sigma Co., St. Louis, Mo., USA. Phenylethanol-amino-n-transferase was isolated from bovine adrenal glands [9].

\section{Results}

Table 1 shows the blood glucose levels, body weight and the concentration of noradrenaline (NA) in the sciatic nerves of four groups of mice. The diabetic mutants and their littermates were of the C57 BL/ KsJ strain while obese and lean mice were from C57 $\mathrm{BL} / 6 \mathrm{~J}$ stock. Both diabetic and obese mice had significantly $(\mathrm{P}<0.001)$ elevated body weight and blood glucose.

Noradrenaline concentrations in the segment of sciatic nerves (contralateral) were similar in diabetic and non-diabetic mice $(0.58 \mathrm{ng} / \mathrm{cm}$ vs $0.67 \mathrm{ng} / \mathrm{cm}$ respectively), but significantly lower in the nerves of obese mutants and their lean littermates $(0.47 \mathrm{ng} / \mathrm{cm}$ and $0.46 \mathrm{ng} / \mathrm{cm}$ ).

Short lasting $(4.5 \mathrm{~h})$ constriction of the sciatic nerves produced no accumulation of NA in two consecutive segments $(1 \mathrm{~cm}$ each) of nerve; however, when the constriction period was extended to $9 \mathrm{~h}$, a marked accumulation of NA was noted in the axons of nondiabetic mice, but very little accumulation in the nerves of diabetic mutants (Table 1). In obese $(\mathrm{ob} / \mathrm{ob})$ and lean mice the accumulation of NA after $9 \mathrm{~h}$ of nerve constriction was similar to that observed in nondiabetic mice (Table 1).

The pattern of distribution of NA along the nerve constricted for $9 \mathrm{~h}$ is shown in Fig. 1. When NA accumulation occurred, as in the nerves of nondiabetic mice, the amine was concentrated in the segment $(1 \mathrm{~cm})$ proximal to the constriction; no accumulation was observed in the second segment above the ligature.

Insulin, administered to diabetic and nondiabetic mice for five days $(10 \mathrm{U} / \mathrm{kg} /$ day $)$, lowered the blood 
Table 2. Influence of insulin on the accumulation of noradrenaline (NA) in the sciatic nerves of genetically diabetic and nondiabetic mice

\begin{tabular}{|c|c|c|c|}
\hline \multirow[t]{2}{*}{ Group } & \multirow{2}{*}{$\begin{array}{l}\text { Blood glucose } \\
(\mathrm{mg} / 100 \mathrm{ml})\end{array}$} & \multicolumn{2}{|c|}{$\mathrm{NA}(\mathrm{ng} / \mathrm{cm}) \pm \mathrm{SEM}$} \\
\hline & & Contralateral & Constricted \\
\hline Nondiabetic & 100 & 0.68 & 1.50 \\
\hline (C57/KsJ ?/+) & \pm 24 & \pm 0.07 & \pm 0.10 \\
\hline Diabetic & 239 & 0.60 & 1.69 \\
\hline$(\mathrm{C} 57 / \mathrm{KsJ} \mathrm{db} / \mathrm{db})$ & \pm 15 & \pm 0.13 & \pm 0.04 \\
\hline
\end{tabular}

Each value is the mean of four determinations. Nerves constricted for $9 \mathrm{~h}$. Insulin (ILETIN, Lilly) regular, $10 \mathrm{U} / \mathrm{kg} / \mathrm{day}$, was administered subcutaneously for five days before ligation of nerves and during the constriction period. Nondiabetic (body weight 34.0 $\pm 1.2 \mathrm{~g}$ ) and diabetic mice (body weight $61.3 \pm 1.7 \mathrm{~g}$ ) were of the same age (46 weeks old)

Table 3. Accumulation of tyrosine hydroxylase in the sciatic nerves of genetically diabetic and nondiabetic mice

\begin{tabular}{llc}
\hline \multirow{2}{*}{ Group } & \multicolumn{2}{l}{$\begin{array}{l}\text { Tyrosine Hydroxylase activity } \\
\text { pmol DOPA formed/cm nerve/hr } \pm \text { SEM }\end{array}$} \\
\cline { 2 - 3 } & Contralateral & Constricted $^{\mathrm{a}}$ \\
\hline Nondiabetic & 44.2 & 68.1 \\
(C57 BL/KsJ ?/+) & \pm 1.9 & \pm 4.8 \\
Diabetic & 42.3 & $54.5^{\mathrm{b}}$ \\
$(\mathrm{C} 57 \mathrm{BL} / \mathrm{KsJ} \mathrm{db} / \mathrm{db})$ & \pm 1.7 & \pm 2.6
\end{tabular}

Each value is the mean of five observations. Diabetic (body weight $56.8 \pm 5.3 \mathrm{~g}$ ) and control (body weight $30.4 \pm 1.2 \mathrm{~g}$ ) were 42 weeks old

a Accumulation in $1 \mathrm{~cm}$ proximal to the ligature after $18 \mathrm{~h}$ constriction

${ }^{b}$ Differs significantly from control $(\mathrm{P}<0.05)$

glucose concentrations (compare glycaemia of Table 1 with that of Table 2), had no effect on the basal concentration of NA, but completely restored its accumulation in the constricted axons of diabetic mice (Table 2). Nondiabetic mice treated with insulin tended to accumulate more NA (Table 2) than nondiabetic mice not treated with the hormone (Table 1 ), but the difference was not significant.

The axonal concentration and the accumulation after nerve ligation of tyrosine hydroxylase activity were examined in diabetic mutants and their normal littermates. Similar levels of enzyme activity were found in the contralateral nerves of the two groups, but less enzyme accumulated in the constricted nerves of diabetic animals (Table 3 ).

\section{Discussion}

The accumulation of NA above a nerve constriction demonstrates the presence of intraaxonal flow in the noradrenergic axons of mouse sciatic nerves, and extends to the mouse a phenomenon well established in other laboratory species [10]. The salient finding of this study concerns the reduced accumulation of NA in the constricted nerves of diabetic mice. Compared to nondiabetic control the decrease was striking $(41 \%)$ and highly significant $(\mathrm{P}<0.001)$. Because NA is stored within complex vesicles, its accumulation reflects the piling up of these organelles above the point of constriction [11]. Storage vesicles as well as the enzymes involved in the biosynthesis of NA are manufactured in the cell bodies of neurons [10] and migrate toward the nerve endings through the intraaxonal transport system $[10,11,12]$. The synthesis of NA, instead, occurs mainly at the nerve terminals, although small amounts of NA are also synthesized in the perikaryon and in the axons [13].

The reduced accumulation of NA in the nerves of diabetic mice relative to their controls may be attributed to decreased availability of NA biosynthetic enzymes caused by the slowing of the transport rate of this material along the axons.

On the basis of the results obtained after $9 \mathrm{~h}$ of constriction we computed the rate of transport according to the equation: $\mathrm{mm} / \mathrm{h}=\frac{\left(\mathrm{C}-\mathrm{C}_{\mathrm{c}}\right) \mathrm{T}}{\mathrm{C}_{\mathrm{c}} / \mathrm{S}}$ where $\mathrm{C}$ is the concentration of NA above constriction, $\mathrm{C}_{\mathrm{c}}$ is the NA concentration in contralateral nerve, $T$ is the period of constriction ( $h$ ) and $S$ the length of segment $(\mathrm{mm})$. In control mice the velocity was $0.74 \mathrm{~mm} / \mathrm{h}$ while in diabetic mice the velocity was only $0.17 \mathrm{~mm} /$ $h$. It is of interest to note that NA containing particles in the sciatic nerves of control mice, like those of other species [10], move at average rates slightly below $1 \mathrm{~mm} / \mathrm{h}$, i. e., via the so-called fast axoplasmic flow.

The substantial difference in the apparent transport velocities well explains the decrease of NA and tyrosine hydroxylase accumulation noted in diabetic adrenergic axons.

Although a decrease of the transport rate of the NA biosynthetic enzymes, particularly tyrosine hydroxylase, appears to be the immediate cause for the decreased accumulation of NA, an understanding of the underlying mechanism for the diabetic abnormality comes from the experiments with the obese mutants and with the insulin treated mice. Neither obesity nor hyperglycaemia seemed to influence the rate of axoplasmic flow. The constricted sciatic nerves of obese mice which show hyperglycaemia (Table 1) did, in fact, accumulate noradrenaline at the same rate as their lean littermates.

On the other hand, administration of insulin to mature diabetic mice induced a complete reversal of the abnormality of NA accumulation. Indeed, these 
results suggest that levels of insulin affect axoplasmic flow in a manner unrelated to the glucose regulation. In this context it should be noted that values of plasma insulin, reported in the literature, indicate that obese mice [14] are hyperinsulinaemic $(336 \mathrm{mU} /$ 1 plasma versus $21 \mathrm{mU} / 1$ for lean control), while mature diabetic mutants [15] have relatively low levels of plasma insulin $(71.1 \mathrm{mU} / 1$ versus $72.3 \mathrm{mU} / 1$ for nondiabetic) although are markedly hyperglycaemic.

The anomalies of axoplasmic flow found in the noradrenergic axons of diabetic animals do not directly explain the lowering of conduction velocities observed in motor nerves. They do, however, indicate that diabetes alters a common property of nerves, i. e., the ability to move constituents from the cell body toward nerve endings. Conceivably the reduced axoplasmic flow of nutrients and materials toward the terminals might result in disturbances of conduction.

Acknowledgements. This work was supported by N. I. H. Grant 5RO1-HL20446 and by funds obtained from Ciba-Geigy.

I wish to express my gratitude to Ms. Thi Nhu-Y Dong for excellent technical assistance.

\section{References}

1. Thomas, P. K., Eliasson, S. G.: Diabetic neuropathy, peripheral neuropathy, vol. 2. Dick, P. J., Thomas, P. K., Lambert, E. H. (Eds.), pp. 956-981. Philadelphia: W. B. Saunders 1975

2. Bischoff, A.: Ultrastructural pathology of peripheral nervous system in early diabetes. Adv. Metab. Disord. 2 [Suppl. 2], 441-449 (1973)

3. Eliasson, S. F.: Nerve conduction changes in experimental diabetes. J. Clin. Invest. 43, 2353-2358 (1964)

4. Sharma, A. K., Thomas, P. K.: Peripheral nerve structure and function in experimental diabetes. J. Neurol. Sci. 23, 1-15 (1974)
5. Schmidt, R. E., Matschinsky, F. M. Godfrey, D. A., Williams, A. D., McDougal, D. B.: Fast and slow axoplasmic flow in sciatic nerve of diabetic rats. Diabetes 24, 1081-1085 (1975)

6. Weise, V. K., Kopin, I. J.: Assay of catecholamines in human plasma: studies of a single isotope radioenzymatic procedure. Life Sci. 19, 1673-1686 (1976)

7. Lowry, O. H., Rosebrough, N. J., Farr, A. L., Randall, R. G.: Protein measurement with the Folin phenol reagent. J. Biol. Chem. 193, 263-275 (1951)

8. Waymire, J. C., Bjur, R., Weiner, N.: Assay of tyrosine hydroxylase by coupled decarboxylation of dopa formed from ${ }^{14} \mathrm{C}$ tyrosine. Anal. Biochem. 43, 588-600 (1971)

9. Molinoff, P. B., Weinshilboum, R., Axeltod, J.: A sensitive enzymatic assay for dopamine- $\beta$-hydroxylase. J. Pharmacol. Exp. Ther. 178, 425-431 (1971)

10. Dahlstrom, A.: Observations on the accumulation of noradrenaline in the proximal and distal parts of peripheral adrenergic nerves after compression. J. Anat. 99, 677-689 (1965)

11. Laduron, P., Belpaire, F.: Transport of noradrenaline and dopamine- $\beta$-hydroxylase in sympathetic nerves. Life Sci. 7, 1-7 (1968)

12. Dahlstrom, A., Haggendal, J.: Studies on the transport and life-span of amine storage granules in a peripheral adrenergic neuron system. Acta Physiol. Scand. 67, 278-288 (1966)

13. Geffen, L. B., Rush, R. A.: Transport of noradrenaline in sympathetic nerves and the effect of nerve impulses on its contribution to transmitter stores. J. Neurochem. 15, 925-930 (1968)

14. Genuth, S. M.: Hyperinsulinism in mice with genetically determined obesity. Endocrinology 84, 386-391 (1969)

15. Coleman, D. L., Hummel, K. P.: The effects of hypothalamic lesions in genetically diabetic mice. Diabetologia 6, 263-267 (1970)

Received: July 5, 1978

and in revised form: September 29, 1978

Dr. A. Giachetti

Università di Milano

Istituto di Farmacologia

Cattedra di Saggi

Via Vanvitelli 32

I-20129 Milano

Italy 